\title{
Restoration potential of eight tree species from a seasonally dry tropical forest in southeast Piauí, Brazil
}

\author{
Andressa Ribeiro ${ }^{1 * \mathrm{iD}}$, Antonio Carlos Ferraz Filho ${ }^{1 \mathrm{iD}}$, Séfora Gil Gomes de Farias ${ }^{1 \mathrm{iD}}$, \\ Bruna Anair Souto Dias ${ }^{1 \mathrm{iD}}$, Helionai Pereira da Silva ${ }^{1 \mathrm{iD}}$
}

${ }^{1}$ Federal University of Piauí, Bom Jesus, Piauí, Brazil

\section{FOREST MANAGEMENT}

\begin{abstract}
Background: The conservation and restoration of forest landscapes is an important aspect of sustainable development. In semi-arid regions these practices are difficulted by the harsh climate of these environments, with low precipitation values and prolonged dry seasons. The objective of this study is to identify tree species from the south of the Brazilian state of Piauí that have potential to be used in forest restoration programs.
\end{abstract}

Results: Data from forest inventory and tree characteristics were used to select eight tree species using target species definition, focusing on species with desirable wood properties, abundance in the study region, favorable dendrometric variables, seed availability, ease of seed germination and seedling growth in nursery and field conditions, among others. These species were then evaluated as candidates for restoration using a framework species approach focusing on the following attributes: (i) $70 \%$ or higher seedling survival in the field; (ii) seedling height of $45 \mathrm{~cm}$ or taller after the first growing season in the field and (iii) $70 \%$ or greater nursery seedling survival.

Conclusion: The species Combretum glaucocarpum, Cenostigma macrophyllum, and Pityrocarpa moniliformis are suitable to be employed in forest restoration programs in the southern region of Piauí, Brazil. Further studies must be carried out to assess the behavior of these and other potential tree species in long term field conditions and under varying silvicultural regimes, a key aspect for forest restoration.

Keywords: Reforestation; Semi-arid environment; Seed germination; Seedling establishment; Species selection.

\section{HIGHLIGHTS}

Seedling height in the nursery is an important indicator for field planting success. Seed immersion for longer periods yielded higher germination and seedling growth. Tree species with superior seedling traits (survival and growth) were identified. Species chosen: Combretum glaucocarpum, Cenostigma macrophyllum, Pityrocarpa moniliformis.

RIBEIRO, A.; FERRAZ FILHO, A. C.; FARIAS, S. G. G; DIAS, B. A. S.; SILVA, H. P. Restoration potential of eight tree species from a seasonally dry tropical forest in southeast Piauí, Brazil. CERNE, v. 27, e-102702, doi: 10.1590/01047760202127012702 


\section{INTRODUCTION}

Brazil had in 2018 a total of 162,840 MW of installed energy matrix (Brasil, 2019), and many powerlines are across forest and native vegetation areas, where the occurrence of fire under transmission lines corridors is responsible for a great number of outages (Clarke et al., 2006; Davis, 2012). Given the climate and vegetation type of Northeast Brazil, the threat of wildfire is a serious concern for powerline corridor managers, leading to widespread power outages and economic loss. Measures taken to reduce fire intensity and thereby minimize risk of faults include: clearance of most vegetation from underneath powerlines; expansion of vegetation clearance around towers; reduction of vegetation maintenance intervals in high risk locations; management based on vegetation and fuel type; alteration of species composition (Çoban et al., 2019; Souza and Vale, 2019).

Tree cover is one of the defining variables of landscapes' ecological functioning, and impact on climate (Hirota et al., 2011). A common practice of powerline land management is to clear all the vegetation from under the lines and towers, especially in fire prone areas (Clarke and White, 2008). However, this might lead to landscape fragmentation, with ecological impacts in the remaining vegetation. The conservation and restoration of forest landscapes is an important aspect of achieving the United Nations Sustainable Development Goals, impacting a wide range of goals such as: improving livelihoods, sustainable consumption and production, food and water security, and climate change mitigation. Understanding how a vegetation community responds to management is the first step in determining the frequency and intensity of the silvicultural interventions required to control the vegetation (Clarke and White, 2008).

Caatinga and Cerrado biomes are represented by seasonally dry tropical forests, composing one of the world's most endangered tropical biomes, with poorly known flora and severely threatened by multiple pressures (Miles et al., 2006; Fernandes et al., 2020). The number of studies focused on the plant communities and growth under transmission lines are small (Wagner et al., 2014; Li and Lin, 2019) and few studies have been found to date that address the question of what the appropriate forest restoration and management under powerlines in Brazilian biomes (Oliveira and Zaú, 1998; Xavier et al., 2007; Machado Neto et al., 2015).

The objective of this study was to identify tree species from the south of Piauí state that have potential to be used in forest restoration programs. Superior tree species were identified by the following traits: success of seed obtention and germination, ease of seedling production and field test performance (growth and survival). The ability of adult individuals of the studied species to regenerate via coppice after being submitted to clearcutting, and the impact of this aspect on species selection, is also discussed.

\section{MATERIAL AND METHODS}

\section{Experimental areas and species selection}

This study is part of a broader project investigating actions to mitigate the fire related risks of failures in power lines and evaluation of maintenance methods for corridors in different areas in Piauí. The powerline influence area under study runs through rural areas of 10 municipalities in the southeast and southwest mesoregions of Piauí state, in a transition zone between the Cerrado and Caatinga biomes (Figure 1). The events of power shutdowns are recurrent, mainly due to wildfires and anthropic factors. The region has a mean annual temperature of $26.9^{\circ} \mathrm{C}$ and annual precipitation of $926 \mathrm{~mm}$, with $89.2 \%$ of the total precipitation occurring during the wet season, from November to April (INMET, 2018). The Aridity Index (annual precipitation/annual potential evapotranspiration) of the region is 0.4 . The short duration of the wet season (less than 180 days) and low Aridity Index characterizes the region as a semi-arid climate type, with seasonally dry tropical forests as the main vegetation type (Allen et al., 2017; Cherlet et al., 2018).

Data from forest inventories were used to obtain the phytosociological and dendrometric values for the most representative tree species of the study region. These inventories were performed in a forest management plan located in Cristino Castro (green dot in Figure 1), as well as under vegetation remnants located in the powerline corridors (Figure 1, left panel). The forest management area in Cristino Castro was also used to investigate the natural regeneration capacity of adult individuals of the studied tree species, by installing an experiment to evaluate the sprouting success and quantity following clearcutting. An area of two hectares located in Alvorada do Gurgueia was used for the planting experiment (red dot in Figure 1).

The initial determination of the studied species were defined by answering questions as describe by Dumroes et al. (2016) related to target species described, according to the scope of the project (e.g. wood properties, bark thickness, abundancy in the study region, dendrometric variables, seed availability). In total eight species were selected: Cenostigma macrophyllum Tul., Combretum glaucocarpum Mart., Copaifera luetzelburguii Harms, Dalbergia cearensis Ducke, Hymenaea martiana Hayne, Luehea paniculata Mart. \& Zucc., Mimosa caesalpiniifolia Benth., and Pityrocarpa moniliformis Benth. All species belong to the Fabaceae family, with exception of $L$. paniculata, which belongs to Malvaceae, and $C$. glaucocarpum to Combretaceae.

Following the selection of the eight study species, the next phase of this study was based on a framework species approach (Elliott et al., 2003), identifying which of these eight previously chosen species can be used as potential candidates for forest restoration programs, focusing on aspects related to ease of seedling production and field test performance.

\section{Seed collection and germination}

Seed collection occurred in different forest fragments around the experiment areas and power lines, as depicted in the left panel of Figure 1. Seed collection occurred from March to October 2018, following each species' phenology, meeting all technical aspects to guarantee the quality of the propagules. Potential vegetation remnants of Caatinga, Cerrado and transition areas were selected to perform the 


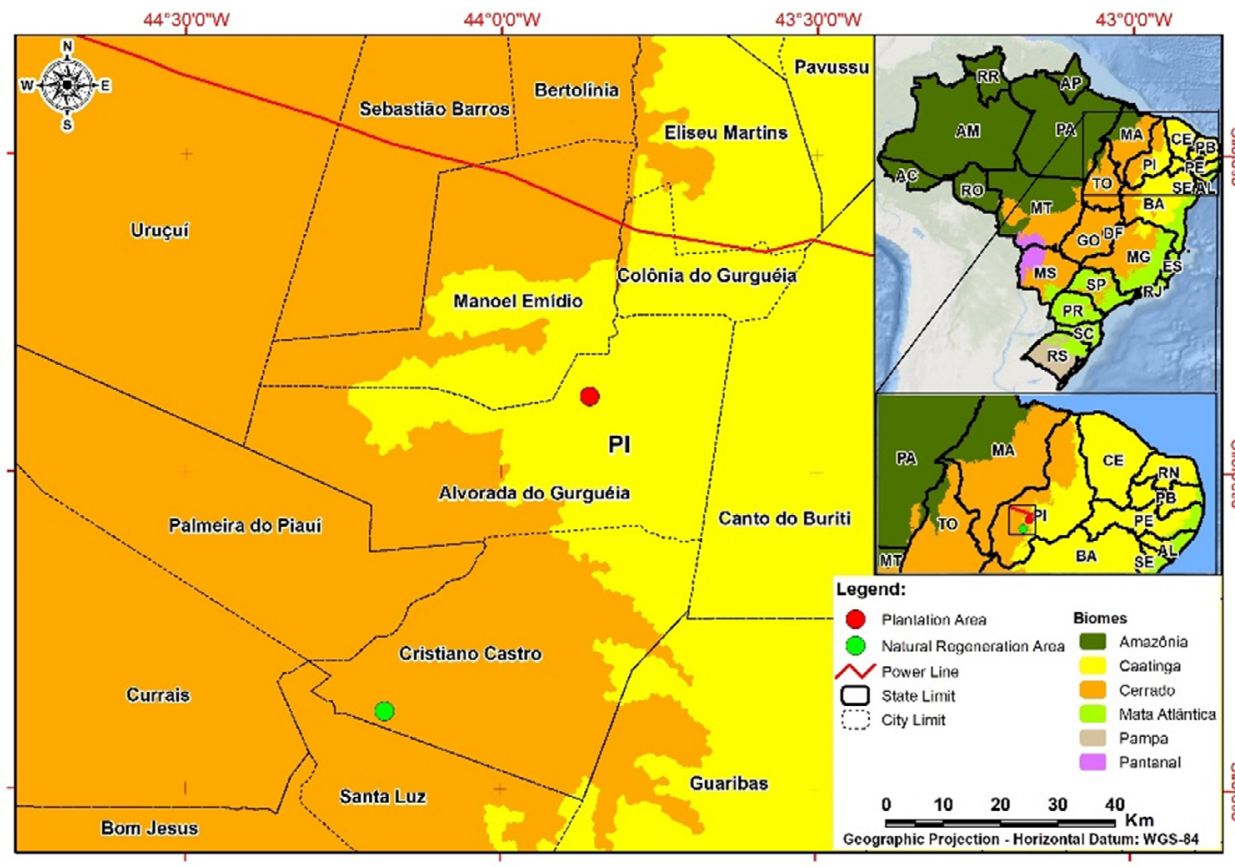

Fig. 1 Map of the location of the Brazilian biomes (upper right), a view of the northeast region of Brazil (lower right), and the region of the study (left) with the location of the power line crossing Piauí cities.

collection from a total of 52 trees, bellowing to the species: Pityrocarpa moniliformis (13), Cenostigma macrophyllum (11), Combretum glaucocarpum (8), Mimosa caesalpiniifolia (6), Hymenaea martiana (5), Copaifera luetzelburguii (4), D. cearesnsis (3) and Luehea paniculata (2). Only healthy trees, with well-formed crowns, dominant aspect and with a minimum distance of $100 \mathrm{~m}$ between themselves were used for seed collection. Fruits collected in the field were taken to the Laboratory of Forest Ecophysiology of the Federal University of Piauí (UFPI), Campus Bom Jesus, for manual processing to obtain the seeds.

The seeds of 4 of the 8 studied species have dormancy. To overcome the dormancy for these species, several methods were tested, according to the literature available for the species or genus, varying the number of treatments performed according to the species and quantity of seeds available. The tested pre-germinative treatments were: control/no treatment (T1); mechanical scarification with 80 grit sandpaper (T2); immersion in sulfuric acid $\left(\mathrm{H}_{2} \mathrm{SO}_{4}\right)$ for 5 (T3), 10 (T4), 15 (T5), 20 (T6), 30 (T7), and 40 minutes (T8); immersion in hydrochloric acid ( $\mathrm{HCl})$ for 5 (T9), 10 (T10), and 15 minutes (T11); immersion in acetic acid $\left(\mathrm{CH}_{3} \mathrm{COOH}\right)$ for 1 (T12), and 2 hours (T13); immersion in water at 80 (T14), 90 (T15), and $100{ }^{\circ} \mathrm{C}$ (T16); immersion in distilled water for 24 (T17), 48 (T18), and 72 hours (T19); mechanical scarification followed by 2 (T20), 6 (T21), and 24-hour (T22) soaking; thermal shock (T23).

These germination tests were performed in a B.O.D germinator (Biochemical Oxigen Demand), under constant temperature of $25^{\circ} \mathrm{C}$, with a 12 hours photoperiod and using paper towels as the substrate for germination. For the species $M$. caesalpiniifolia the substrate was set up in the form of rolls, while for the other species the seeds were placed upon the paper substrate. The substrate was wet in the proportion of 2.5 times the weight of dry paper. The tests were performed with four replicates of 25 seeds each.

The germination percentage, germination speed index, height of the seedling, length of the roots, above and belowground dry mass were evaluated in these experiments, according to Maguire (1962) and Guedes et al. (2013). For each measured variable, an analysis of variance (ANOVA) was performed per species. If a significant difference between treatments (considering a 95\% confidence level) was detected in the ANOVA, the Scott-Knott post hoc test was performed to distinguish between the different treatments (also at 95\% confidence level). For each species, the different mean groups of each of the 6 evaluated variables were awarded a score, being 1 for the highest group, 2 for the second highest, and so on. The treatment that presented the lowest ranked sum for the 6 different tested seed germination and seedling growth variables was considered the best one for each studied species.

For all species, sowing and experiments were performed following seed analysis protocols and available literature (Lima Junior et al., 2010; Bewley, 2013). A seed was considered germinated if it yielded a normal seedling, presenting hypocotyl, root, epicotyl, apical meristem, and the first pair of expanding leaves. Seed moisture content was used as a proxy variable for quality and storability for all studied species.

\section{Seedling production}

An experiment was performed with the eight species to evaluate the effect of five doses of controlledrelease fertilizer (CRF - 0.0; 0.6; 1.2; 1.8; $2.44 \mathrm{~kg}$ of CRF per $\mathrm{m}^{3}$ of planting substrate) on seedling production. The CRF used was Osmocote ${ }^{\circledR}$, with $18 \mathrm{~N}: 5 \mathrm{P}: 8 \mathrm{~K}$ and 5-month release formulation. Each species/treatment received five repetitions each, being each repetition 15 seedlings grouped together in a planting tray. The seedlings were sown in 
ribbed (for better direction of the root system) tube-type containers, with a hole at the bottom and $50 \mathrm{~cm}^{3}$ capacity. A commercial substrate (Carolina Soil ${ }^{\circledR}$ ) was used to fill the containers, using a proportion of 45 liters of substrate for 5 liters of water, plus the CRF treatment dose. Manual sowing was performed at a depth of $1.5 \mathrm{~cm}$ in the containers, which were packed in trays and taken to a greenhouse, located in UFPI/Bom Jesus, with automatic irrigation system 3 times a day for 30 minutes, with 4-hour intervals.

The height, root collar diameter and survival of each seedling was recorded 78 days after planting. For the species Mimosa caesalpiniifolia, 3 repetitions of the treatment dose of $1.2 \mathrm{~kg}$ did not yield viable seedlings, making the total number of observations 197. The dose of CRF that yielded the highest seedling growth and survival was assessed by fitted linear models for each of the measured variable. The models were fitted independently for each of the tested species and variables. A linear and quadratic model were tested for each variable, selecting the model with the highest adjusted coefficient of determination, considering a confidence level of $95 \%$. The fitted models were then used to identify which dose of controlled-release fertilizer yielded the largest seedlings with the lowest mortality levels.

\section{Seedling survival in field conditions}

The survival and growth of the produced seedlings were evaluated in natural field conditions during the first growth season. An experimental plantation was installed 5 months after sowing of the seedlings. Each species was planted under 6 different square spacings, beginning with $2.5 \mathrm{~m}$ and ending with $5 \mathrm{~m}$, with a $0.5 \mathrm{~m}$ interval between the treatments. Each spacing was planted on plots with 3 lines and 9 trees, totaling 27 trees per plot. Due to the smaller number of seedlings available for 3 species (L. paniculata, $D$. cearensis and $M$. caesalpiniifolia), a differentiated spatial arrangement was adopted, with 2 spatial arrangements ( $3 \times 3$ and $5 \times 5 \mathrm{~m}$ ) on plots with 5 lines and 4 trees, totaling 20 plants per plot.

The field experiment was installed in an experimental farm belonging to the Federal University of Piauí, located in the municipality of Alvorada do Gurgueia, Piauí. The experiment was installed in an area located at approximately $1 \mathrm{~km}$ from the Gurgueia River, at an elevation of 220 meters above sea level (Figure 1). This area has a slope of 3 to $4 \%$, with an aspect of $315^{\circ}$ (northwest orientation). At the time of the plantation, the area was under fallow and was covered by scrub vegetation, being previously used for agricultural crops and animal grazing.

Two months before field planting, the ground vegetation was mechanically cleared, followed by soil tillage and insect control. A soil analysis was performed to a depth of $60 \mathrm{~cm}$, revealing that the plantation area is composed of sandy soil (93\% of sand), with acid pH (5.2) and low organic matter content $(0.5 \%)$. The seedlings were planted by hand in the field in February 2019. Planted seedling had an average of height of $14 \mathrm{~cm}$ and root collar diameter of $3 \mathrm{~mm}$. Soil nutrient content was corrected (based on the soil analysis results) by application (adjacent to the planting pit) of $120 \mathrm{~g}$ of NPK (5-30-15) and $50 \mathrm{~g}$ of lime, one week after planting.
Monthly evaluation of the experiment occurred up to 10 months after planting, evaluating seedling survival and measuring the height and root collar diameter with a ruler and digital caliper, respectively. The seedlings that had died were replanted two months after planting. Weeding was performed manually around the seedlings on every measurement occasion.

The behavior of the different species under field conditions was evaluated visually and by Pearson's correlation test between the mean root collar diameter, height, and survival 10 months after planting. A correlation was also performed between these variables and the root collar diameter, height, and survival of the seedlings in nursery conditions.

\section{Natural regeneration experiment}

The last experiment conducted consisted in evaluating the sprouting potential of adult trees growing in their natural environment. This was done to evaluate the potential of seedling production via asexual procedures, in which the use of rejuvenated material is a prerequisite for mass propagation (Arnaud et al., 1993; Kumar et al., 2019). Juvenile propagules from adult trees can be obtained by clearcutting the tree (Stuepp et al., 2017), stimulating epicormic shoot production for some species.

Thus, we monitored the sprouting behavior of 600 clearcut tree stumps to investigate the potential of the different studied species to emit sprouts. For this, two $90 \mathrm{x}$ $30 \mathrm{~m}$ plots were evaluated in a forest management area in Cristino Castro, Piauí (Figure 1). These plots were clearcut in December 2017 and June 2018. After cutting each tree, its botanical classification was made, and the stump (10 to 30 $\mathrm{cm}$ tall) was identified. Six months after the trees were cut, we evaluated whether the stump was capable of emitting sprouts. We also measured the height of the tallest sprout and counted the number of sprouts per stump for the trees that successfully sprouted.

\section{RESULTS}

\section{Germination processes}

Table 1 presents the relevant results for the studied species, including results of variables related to seed germination and seedling size. Fire tolerance shown in Table 1 was attributed according to previous tests on volatile matter, ash content, fixed carbon, and heating values for wood and bark of the studied species.

The species C. glaucocarpum, C. macrophyllum, $D$. cearensis and $L$. paniculata did not present seed dormancy and therefore did not need any pre-germination treatment. The best pre-germination treatments for species P. moniliformis and $M$. caesalpiniifolia was immersion in sulfuric acid for 10 to 15 minutes, while for the species $H$. martiana the best treatment was immersion in hydrochloric acid for 45 minutes. None of the tested pre-germination treatments presented statistical difference for the species C. luetzelburguii. Only the pre-germination treatments for the species $P$. moniliformis and $M$. caesalpiniifolia yielded 
Tab. 1 General information of the studied species and results of the seed pre-germination treatment experiment: a) seed moisture content (\%), b) seed germination (\%), c) germination speed index, d) height of the seedling (cm), e) length of the roots $(\mathrm{cm}), \mathrm{f})$ aboveground dry mass ( $\mathrm{mg})$, and $\mathrm{g}$ ) belowground dry mass (mg).

\begin{tabular}{|c|c|c|c|c|c|c|c|c|c|c|c|c|c|}
\hline $\begin{array}{l}\text { Scientific } \\
\text { name }\end{array}$ & $\begin{array}{l}\text { Local name } \\
\text { (Piauí) }\end{array}$ & $\begin{array}{c}\text { Fire } \\
\text { tolerance }\end{array}$ & $\begin{array}{l}\text { Fruiting } \\
\text { time }\end{array}$ & Fruit type & a & $b^{*}$ & c & $d$ & e & $f$ & g & $\begin{array}{c}\text { Kind of } \\
\text { dormancy }\end{array}$ & $\begin{array}{c}\text { Dormancy- } \\
\text { breaking } \\
\text { treatments }\end{array}$ \\
\hline $\begin{array}{l}\text { Cenostigma } \\
\text { macrophyllum }\end{array}$ & $\begin{array}{l}\text { canela de velho, } \\
\text { caneleiro }\end{array}$ & Yes & Mar-Jul & $\begin{array}{c}\text { Dry } \\
\text { dehiscent }\end{array}$ & 6.4 & - & - & - & - & & - & $\begin{array}{c}\text { No } \\
\text { dormancy }\end{array}$ & - \\
\hline $\begin{array}{l}\text { Combretum } \\
\text { glaucocarpum }\end{array}$ & supaúba, sipaúba & No & May-Sep & $\begin{array}{c}\text { Dry } \\
\text { indehiscent }\end{array}$ & 7.9 & - & - & - & - & & - & $\begin{array}{c}\text { No } \\
\text { dormancy }\end{array}$ & - \\
\hline $\begin{array}{c}\text { Copaifera } \\
\text { luetzelburguii }\end{array}$ & $\begin{array}{c}\text { copaíba, pau } \\
\text { d'óleo }\end{array}$ & Yes & Jul-Oct & $\begin{array}{c}\text { Dry } \\
\text { dehiscent }\end{array}$ & 6.6 & 16.0 & 0.3 & 3.9 & 7.1 & 0.2 & 0.4 & Physical & Not significant \\
\hline $\begin{array}{l}\text { Dalbergia } \\
\text { cearensis }\end{array}$ & $\begin{array}{c}\text { coração de negro, } \\
\text { violeta }\end{array}$ & No & May-Aug & $\begin{array}{c}\text { Dry } \\
\text { indehiscent }\end{array}$ & 6.1 & - & - & - & - & - & - & $\begin{array}{c}\text { No } \\
\text { dormancy }\end{array}$ & - \\
\hline $\begin{array}{l}\text { Hymenaea } \\
\text { martiana }\end{array}$ & $\begin{array}{l}\text { jatobazinho, } \\
\text { jatobá miúdo }\end{array}$ & Yes & Aug-Oct & $\begin{array}{c}\text { Dry } \\
\text { indehiscent }\end{array}$ & 7.2 & 17.5 & 0.1 & 17.5 & 15.3 & 22.8 & 0.5 & Physical & $\mathrm{HCl}(45 \mathrm{~min})$ \\
\hline $\begin{array}{l}\text { Luehea } \\
\text { paniculata. }\end{array}$ & $\begin{array}{l}\text { açoita cavalo, } \\
\text { açoita graúdo }\end{array}$ & Yes & Jul-Aug & $\begin{array}{c}\text { Dry } \\
\text { dehiscent }\end{array}$ & 8.2 & - & - & - & - & - & - & $\begin{array}{c}\text { No } \\
\text { dormancy }\end{array}$ & - \\
\hline $\begin{array}{c}\text { Mimosa } \\
\text { caesalpiniifolia }\end{array}$ & $\begin{array}{c}\text { sabiá, sansão do } \\
\text { campo }\end{array}$ & Yes & Sep-Dec & $\begin{array}{c}\text { Dry } \\
\text { indehiscent }\end{array}$ & 5.7 & 94.5 & 3.6 & 3.2 & 2.8 & 0.0 & 0.0 & Physical & $\begin{array}{c}\mathrm{H}_{2} \mathrm{SO}_{4} \\
(10-15 \text { min })\end{array}$ \\
\hline $\begin{array}{l}\text { Pityrocarpa } \\
\text { moniliformis }\end{array}$ & $\begin{array}{c}\text { angico de } \\
\text { bezerro, } \\
\text { catanduva }\end{array}$ & No & Jul-Sep & $\begin{array}{c}\text { Dry } \\
\text { dehiscent }\end{array}$ & 6.0 & 90.5 & 4.3 & 3.2 & 3.8 & 12.5 & 2.1 & Physical & $\begin{array}{c}\mathrm{H}_{2} \mathrm{SO}_{4} \\
(10-15 \mathrm{~min})\end{array}$ \\
\hline
\end{tabular}

*Values in columns b through $g$ are for the best dormancy-breaking treatments; for C. luetzelburguii these values are from the only successful repetition from the mechanical scarification treatment.

satisfactory results, increasing the germination rates from 10\% (control) to over $90 \%$ (best treatment).

\section{Seedling production}

Figure 2 shows the behavior of the seedling survival, height and root collar diameter growth in relation to the different controlled-release fertilizer (CRF) doses tested. The data presented in Figure 2 were used to fit the linear models that describe the effect of CRF application in seedling survival and growth in the nursery (Table 2). These models were in turn used to identify which dose of controlledrelease fertilizer yielded the largest seedlings with highest survival (Table 2), being the maximum recommended dose per species limited to $2.4 \mathrm{~kg}$ of controlled-release fertilizer per $\mathrm{m}^{3}$ of substrate (i.e. the highest tested dose in this study). Table 2 also shows the percentual growth that the optimum controlled-release fertilizer dose promoted in relation to the control treatment (i.e. no added controlledrelease fertilizer).

\section{Field planting trial and natural regeneration experiment}

Figure 3 shows the results for the growth of the root collar diameter, height, and survival 10 months after seedling planting. In Figure 3 the initial spacings are presented grouped together by species, considering that in 10 months the trees have not started competing for growing space. Table 3 shows the results for the natural regeneration experiment.

\section{DISCUSSION}

Information on the propagation and management of native tree species, specifically on aspects related to seed storage, germination and quality, are necessary for an effective contribution to environmental conservation (Halme et al., 2013; Silva et al., 2017; Koutouan-Kontchoi et al., 2020). We found that seed moisture content after field collection ranged from 6 to $8 \%$ for all species (Table 1). The best selected pre-germination treatments in Table 1 for $P$. moniliformis, M. caesalpiniifolia and $H$. martiana were the maximum tested immersion times for each species. Thus, the immersion of seeds for longer periods might yield better germination and seedling growth, especially for $H$. martiniana, which presented low germination rates (17.5\%). Nevertheless, this was the species that presented the largest seedling growth, presenting seedling that were 3 times higher than the next tallest seedling.

C. luetzelburguii did not present statistically significant differences for any of the evaluated germination and seedling growth attributes under any of the pregermination treatments tested. For this species, only 5 of the 20 repetitions yielded germinated seeds, being $30 \%$ germination the highest value achieved (from the mechanical scarification treatment). All species that presented seed dormancy belong to the Fabaceae family, which corroborates with the premise that the most common dormancy mechanism in legume seeds is related to the impermeability of the integument (Bewley et al., 2013).

Regarding seedling growth in the nursery, we found that the response to the controlled-release fertilizer dose varied according to the studied species (Figure 2). Of the 8 tested species, 7 presented a statistically significant impact on height, root collar diameter growth or seedling survival with fertilizer application (Table 2). The fact that most of the relations were quadratic indicate that the maximum tested fertilizer dose (2.4 kg of controlled-release fertilizer per $\mathrm{m}^{3}$ of substrate) was correctly dimensioned, with most species presenting lower growth increments at higher doses. 
Only the species $H$. martiana did not present increase in seedling growth and survival with the addition of CRF. The application of CRF increased the overall seedling root collar diameter by $18.6 \%$, height by $60.4 \%$ and survival by $45.2 \%$. The higher impact of the CRF in seedling height rather than diameter is in conformity with a tree's growth allocation
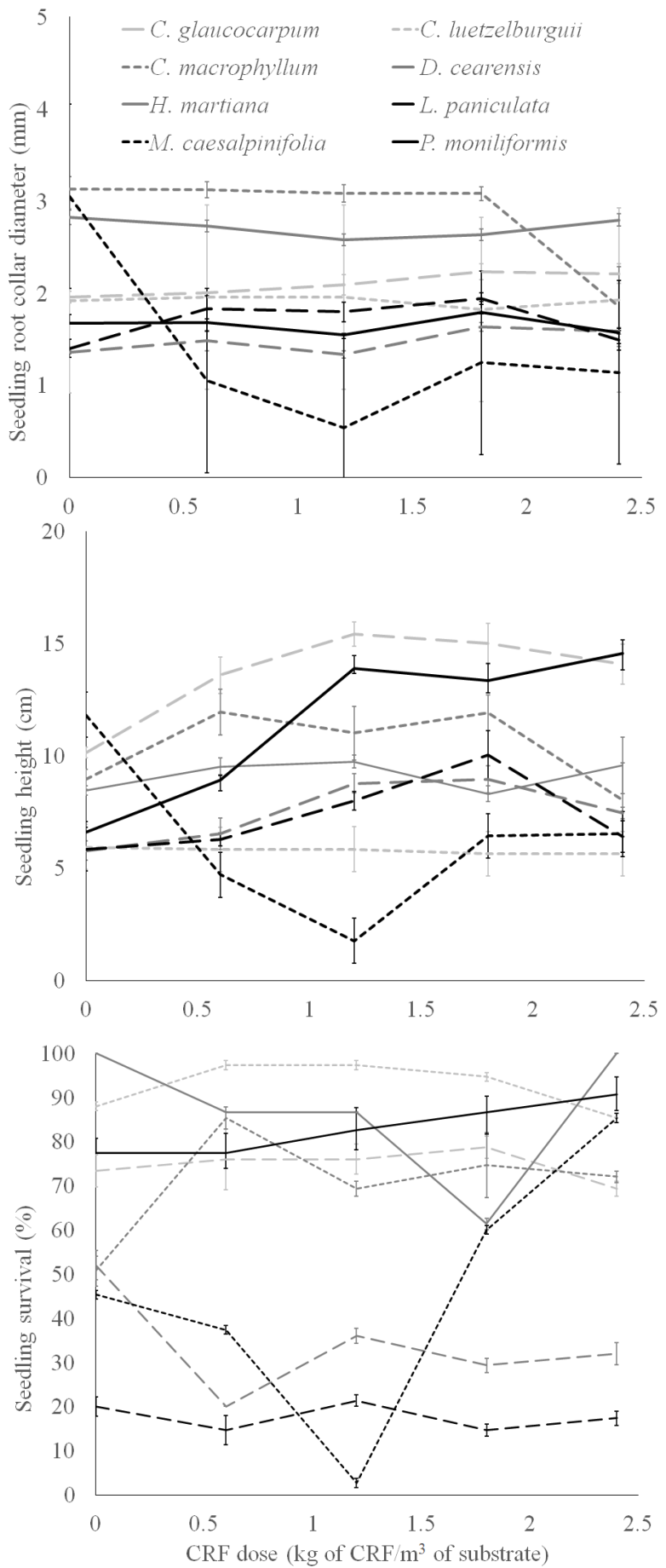

Fig. 2 Seedling root collar diameter, height, and survival for 8 tree species in relation to different controlled-release fertilizer (CRF) doses 78 days after sowing. Vertical bars represent +/- one standard error. priority, with foliage growth ranked as more important than diameter growth (Dobbertin 2005). A mean dose of $1.7 \mathrm{~kg}$ of CRF per $\mathrm{m}^{3}$ of substrate was found to produce the best overall results. However, since the best fertilizer doses varied from species to species, in our case from 0.7 to $2.4 \mathrm{~kg}$, it is important to identify the correct dose for each species.
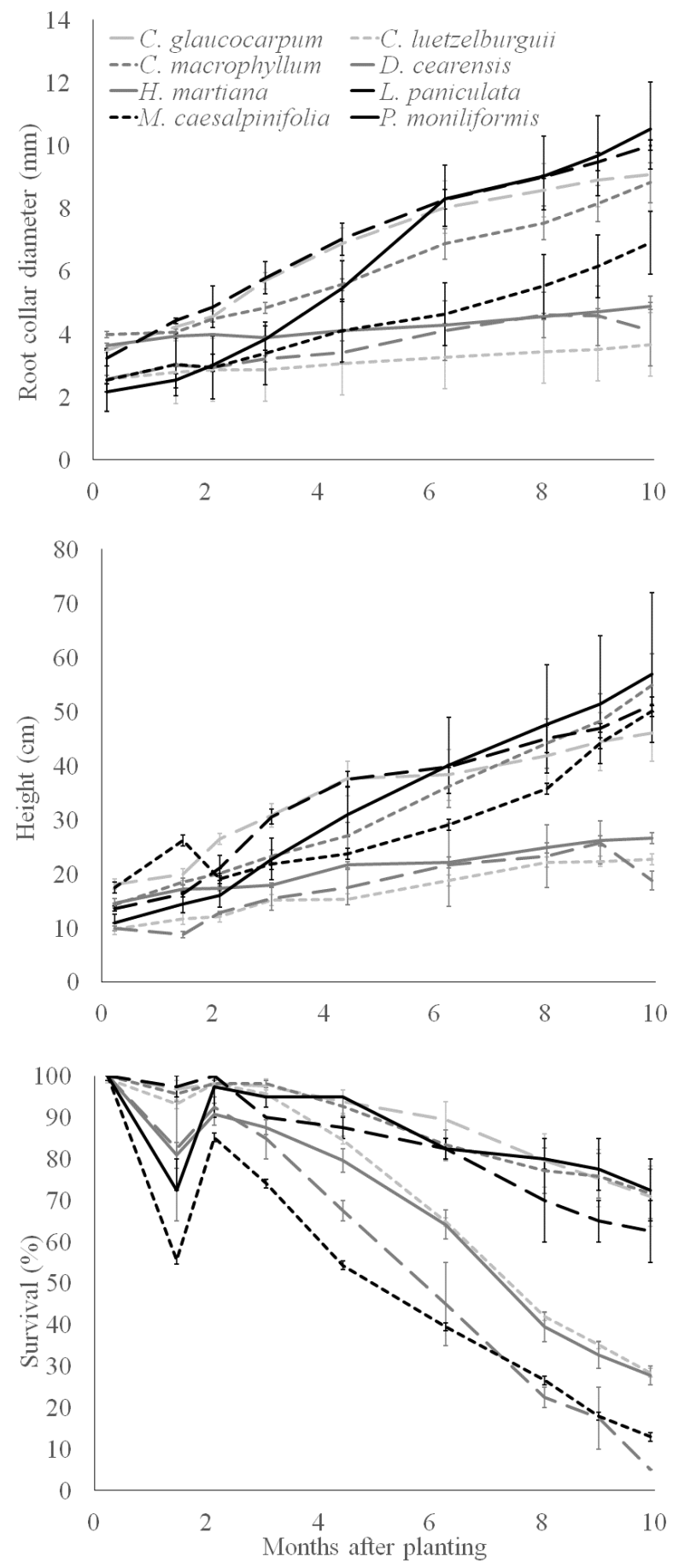

Fig. 3 Development of the root collar diameter, height, and survival for the eight different tree species 10 months after planting at the experimental farm of the Federal University of Piauí, Alvorada do Gurgueia, Brazil. Vertical bars indicate +/- one standard error. 
Tab. 2 Model coefficients and adjusted coefficient of determination $\left(R^{2}\right)$ of the linear models used to describe the seedling's root collar diameter, height, and survival in relation to different doses of controlled-release fertilizer (CRF) for the eight evaluated species.

\begin{tabular}{|c|c|c|c|c|c|c|c|c|c|}
\hline Var. & Species & $\beta_{0}$ & $\beta_{1}$ & $\beta_{2}$ & $R^{2}(\%)$ & Control* & Best value & Best CRF dose & $\%$ increase \\
\hline \multirow{8}{*}{$\begin{array}{l}\text { Root collar diameter } \\
\qquad(\mathrm{mm})\end{array}$} & C. glaucocarpum & 1.97 & 0.11 & - & 20.3 & 2.0 & 2.3 & 2.4 & 14.7 \\
\hline & C. luetzelburguii & - & - & - & - & 1.9 & 1.9 & 0.0 & 0.0 \\
\hline & C. macrophyllum & 3.04 & 0.70 & -0.47 & 44.7 & 3.1 & 3.3 & 0.7 & 5.2 \\
\hline & D. cearensis & 1.36 & 0.10 & - & 19.4 & 1.4 & 1.6 & 2.4 & 17.6 \\
\hline & H. martiana & 2.84 & -0.34 & 0.13 & 17.7 & 2.8 & 2.8 & 0.0 & 0.0 \\
\hline & L. paniculata & 1.40 & 0.81 & -0.32 & 35.7 & 1.4 & 1.9 & 1.3 & 36.7 \\
\hline & M. caesalpinifolia & 2.87 & -3.03 & 1.00 & 71.6 & 3.1 & 3.1 & 0.0 & 0.0 \\
\hline & P. moniliformis & - & - & - & - & 1.7 & 1.7 & 0.0 & 0.0 \\
\hline \multicolumn{6}{|c|}{ Mean root collar diameter } & 2.2 & 2.3 & 1.7 & 18.6 \\
\hline \multirow{8}{*}{ Height $(\mathrm{cm})$} & C. glaucocarpum & 10.24 & 6.75 & -2.16 & 58.0 & 10.2 & 15.5 & 1.6 & 52.7 \\
\hline & C. luetzelburguii & - & - & - & - & 5.9 & 5.9 & 0.0 & 0.0 \\
\hline & C. macrophyllum & 9.06 & 5.35 & -2.36 & 21.7 & 9.0 & 12.1 & 1.1 & 34.9 \\
\hline & D. cearensis & 5.43 & 4.07 & -1.30 & 45.4 & 5.8 & 8.6 & 1.6 & 49.1 \\
\hline & H. martiana & - & - & - & - & 8.5 & 8.5 & 0.0 & 0.0 \\
\hline & L. paniculata & 5.21 & 4.57 & -1.56 & 22.7 & 5.8 & 8.6 & 1.5 & 46.4 \\
\hline & M. caesalpinifolia & 11.18 & -11.96 & 4.37 & 65.4 & 11.8 & 11.8 & 0.0 & 0.0 \\
\hline & P. moniliformis & 6.30 & 7.09 & -1.54 & 81.2 & 6.6 & 14.4 & 2.3 & 118.9 \\
\hline \multicolumn{6}{|c|}{ Mean height } & 7.9 & 10.7 & 1.6 & 60.4 \\
\hline \multirow{8}{*}{ Survival (\%) } & C. glaucocarpum & - & - & - & - & 73.3 & 73.3 & 0.0 & 0.0 \\
\hline & C. luetzelburguii & 88.41 & 17.69 & -7.92 & 42.4 & 88.0 & 98.3 & 1.1 & 11.7 \\
\hline & C. macrophyllum & 56.37 & 30.77 & -10.60 & 26.3 & 50.7 & 78.7 & 1.5 & 55.3 \\
\hline & D. cearensis & 46.65 & -27.32 & 9.26 & 33.6 & 52.0 & 52.0 & 0.0 & 0.0 \\
\hline & H. martiana & 103.24 & -41.64 & 15.59 & 45.8 & 100.0 & 100.0 & 0.0 & 0.0 \\
\hline & L. paniculata & - & - & - & - & 20.0 & 20.0 & 0.0 & 0.0 \\
\hline & M. caesalpinifolia & 48.27 & -58.45 & 31.48 & 70.2 & 45.3 & 89.3 & 2.4 & 97.1 \\
\hline & P. moniliformis & 75.73 & 6.00 & - & 23.8 & 77.3 & 90.1 & 2.4 & 16.6 \\
\hline \multicolumn{6}{|c|}{ Mean survival } & 63.3 & 75.2 & 1.8 & 45.2 \\
\hline \multicolumn{6}{|c|}{ Overall mean dose } & & & 1.7 & 41.4 \\
\hline
\end{tabular}

${ }^{\star}$ Control = value of the root collar diameter, height, and survival for the unfertilized treatment; Best value = value of the root collar diameter, height and survival using the Best CRF dose. Overall means were computed excluding the zero values for the Best value, Best CRF dose and \% increase columns.

Regarding seedling production for individual species, we found that the seedling nursery survival of most species was adequate, with values above $70 \%$. Only the species $D$. cearensis and $L$. paniculata presented low survival values ( $52 \%$ and $20 \%$, respectively). Mean height of the seedlings was $10.7 \mathrm{~cm}$, with the species $P$. moniliformis and $C$. glaucocarpum presenting the highest values of 15 $\mathrm{cm}, 78$ days after sowing. Root collar diameter did not present marked differences amongst the species, with a mean value of $2.3 \mathrm{~mm}$.

Survival in field conditions (Figure 3), an important aspect of forest restoration (Grossnickle, 2012; Dumroese et al., 2016), was over $70 \%$ for the following species: $P$. moniliformis, C. macrophyllum; C. glaucocarpum. This value characterizes these species as possessing excellent survival in field conditions (Elliott et al., 2003; Pakkad et al., 2003). During the months of June to September no precipitation was registered in the meteorological station located in Bom Jesus (95 kilometers southwest of the planting area), as is common in the region. However, the accumulated precipitation during the field experiment monitoring (February to December of 2019) was $1017 \mathrm{~mm}$, a value $23 \%$ higher than the climatological normal for this period (INMET, 2018). This might have assisted the survival of the aforementioned species. The remaining species presented survival values below $30 \%$, except for L. paniculata, which presented $62.5 \%$ survival. Seedling height growth in the field 10 months after planting was similar and above $45 \mathrm{~cm}$ for the species: P. moniliformis; C. macrophyllum; L. paniculata; $M$. caesalpinifolia; C. glaucocarpum. Diameter at ground level growth followed the same pattern as height.

Out of all the tested variables related to seedling growth in nursery conditions, only height (Best values column in Table 2) presented significant correlation with the seedling's diameter $(0.7, p=0.04)$, height $(0.7, p=0.05)$, and survival (0.6, $p=0.12$ ) in field conditions 10 months after planting, showing that nursery seedling height is an important indicator of field planting success. Field survival 10 months after planting was significantly correlated with the seedling's root collar diameter $(0.9, p=<0.01)$ and height $(0.7, p=<0.04)$, where thicker and taller seedlings that had a better chance of survival.

One option for species that for some reason have difficulty of seedling production (e.g. low yield from trees, low germination rate, seed dormancy) is to apply micropropagation techniques, such as the ones presented in Barroso et al. (2018). For instance, Maggioni et al. (2020) showed that the mini-cutting technique is a viable option to 
Tab. 3 Mean values of sprouting capacity (\% regeneration), height of the tallest sprout ( $h$ ), and number of sprouts per stump ( $\mathrm{N}$ sprouts/stump) for the different tree species studied six months after clearcutting. $\mathrm{N}$ stumps indicates the number of trees monitored.

\begin{tabular}{ccccc}
\hline Species & N stumps & \% regeneration & h $(\mathrm{cm})$ & N sprouts/stump \\
\hline C. macrophyllum & 233 & 91.0 & 107.2 & 16.8 \\
C. glaucocarpum & 184 & 85.9 & 128.4 & 7.6 \\
D. cearensis & 3 & 66.7 & 53.5 & 35.5 \\
H. martiana & 56 & 89.3 & 102.9 & 11.3 \\
L. paniculata & 2 & 100.0 & 92.0 & 23.0 \\
M. caesalpiniifolia & 27 & 92.6 & 154.7 & 12.9 \\
P. moniliformis & 95 & 13.7 & 110.8 & 15.1 \\
Total/Mean & 600 & 77.0 & 107.1 & 17.5 \\
\hline
\end{tabular}

produce Drimys brasiliensis seedlings, a tree species from the Brazilian Atlantic Forest with seed dormancy.

Most species in our study presented adequate sprouting 6 months after cutting, with survival rates above 85\% (Table 3). Thus, rejuvenation for these species via cutting is a viable option. The species $D$. cearensis and $P$. moniliformis presented the lowest stump sprouting, with the former displaying only $14 \%$ survival. The number of sprouts per stump was considered high, with an average of 17.5 sprouts/stump. These results are in conformity with those reported by Lima et al. (2018), who found a $63.4 \%$ sprouting capacity in a Caatinga vegetation located in Pernambuco state, two years after clearcutting. The number of sprouts per stump reported by the previous authors was 5.7, significantly lower than we found, probably due to the longer period after cutting (two years versus six months).

A tree's ability to recover from clearcutting can be considered is a key element of resilience in savanna woodlands (Aerts et al., 2008). From a restoration point of view, species that have high ability of sprouting after clearcutting are advantageous, providing synergy between organic waste recycling, biomass production and longterm risk management for contaminated land (Paulson et al., 2003). Some situations might require the selection of species with low sprouting potential. For example, in fire hazard zones, one option of powerline corridor management is the complete removal of vegetation using short rotation times (Clarke and White, 2008). In these cases, the distinction of tree species than can be eliminated from a determined area by clearcutting (e.g. P. moniliformis) from those that have high sprouting capacity (e.g. C. macrophyllum) is important, since the latter will require additional silvicultural operations for elimination. The species $P$. moniliformis was the one that presented the highest field survival, with a $72.5 \%$ survival rate (Figure 3). This species was also the one with the highest seedling belowground biomass production (Table 1), indicating that species with higher root biomass allocation are also the ones with higher seedling survival (Lloret et al., 1999).

Some of the species studied here have potential to be used in forest restoration programs. A method to identify which species to use in these programs is the framework species approach. Originally developed in Queensland, Australia, this method has been successfully used to guide restoration practices in a variety of ecosystems, such as tropical forests in Panama and Thailand (Boeschoten et al.,
2020; Waiboonya and Elliott, 2020) to dryland vegetation in Argentina (Pérez et al., 2019). This method involves planting mixtures of 20 to 30 tree species in a single step to identify characteristics pertinent to ecosystem restoration. Examples of these characteristics include: high field survival; high growth; large crown for weeding by shading; attractiveness to fauna; vertical stratification of the forest; resistance to disturbances; ease of propagation in nurseries; reliable seed availability (Elliott et al., 2003; Pérez et al., 2019).

Based on attributes reported by Elliott et al. (2003), Pakkad et al. (2003), and Pérez et al. (2019), we identified the species in this study with the highest potential for use in forest restoration programs and candidates for domestication those that meet the following requirements: (i) $70 \%$ or higher seedling survival in the field; (ii) a seedling height of $45 \mathrm{~cm}$ or taller after the first growing season in the field and (iii) $70 \%$ or greater seedling survival in the nursery. We found that three species were able to meet these requirements: $C$. glaucocarpum; C. macrophyllum; P. moniliformis.

\section{CONCLUSION}

We found that the species Combretum glaucocarpum, Cenostigma macrophyllum and Pityrocarpa moniliformis are suitable to be employed in forest restoration programs in the southern region of Piauí, Brazil, be it under power lines or other reforestation purposes, given these species' high seedling survival and growth in nursery and field conditions. Further studies must be carried out to access the behavior of these and other potential tree species in long term field conditions and under varying silvicultural regimes, a key aspect for forest restoration.

\section{ACKNOWLEDGEMENT}

This work was supported financially by the Transmissora Aliança de Energia Elétrica S.A. (TAESA) through the research and development program of the Agência Nacional de Energia Elétrica (Brazilian Electricity Regulatory Agency - ANEEL) "PD-07130-0044/2016: Estudo de ações para mitigação de riscos de desligamentos das linhas de transmissão por queimadas e avaliação de métodos de manutenção de faixas de servidão". The last author of this study receives financial support from the Fundação de Amparo a Pesquisa do Piauí (FAPEPI). The 
authors thank Ekocap and Gurguéia Manejo Florestal for support in the data gathering process.

\section{AUTHORSHIP CONTRIBUTION}

Project Idea: $A R$

Funding: AR

Database: AR, ACFF, SGGF, BASD, HPS

Processing: AR, ACFF, HPS

Analysis: AR, ACFF, SGGF, BASD, HPS

Writing: $A R, A C F F, S G G F$

Review: AR, ACFF, SGGF, BASD

\section{REFERENCES}

AERTS, R.; NOVEMBER, E.; MAES, W.; VAN DER BORGHT, I.; NEGUSSIE, A.; AYNEKULU, E.; HERMY, M.; MUYS, B. In situ persistence of African wild olive and forest restoration in degraded semiarid savanna. Journal of Arid Environments, v. 72, n. 6, p. 1131-1136, 2008.

ALLEN, K.: DUPUY J. M. GEI, M. G: HULSHOF C: MEDVIGY, D: PIZANO C.: SALGADO-NEGRET, B.: SMITH, C. M.: TRIERWEILER, A.; BLOEM, S. J. V. WARING, B. G.; XU, X.; POWERS, S. J. Will seasonally dry tropical forests be sensitive or resistant to future changes in rainfall regimes? Environmental Research Letters, v. 12, n. 2, p. 023001, 2017

ARNAUD, Y.; FRANCLET, A.; TRANVAN, H.; JACQUES, M. Micropropagation and rejuvenation of Sequoia sempervirens (Lamb) Endl: a review. Annales des sciences forestières, v. 50, n. 3, p. 273-295, 1993.

BARROSO, D. G.; OLIVEIRA, T. P. F.; SIQUEIRA, D. P.; LAMÔNICA, K. R. CARVALHO, G. C. M. Ministumps productivity and rooting of Khaya ivorensis A. Chev mini-cuttings treated with IBA. Cerne, v. 24, n. 2, p. 114-120, 2018

BEWLEY, J. D. Seeds: physiology of development, germination and dormancy. Springer, 2013. 392p.

BOESCHOTEN, L. E. VAN BREUGEL, M.: BAILON, M.: BALBUENA, J: NUÑEZ M.; CEREZO, A.; HALL, J. S. Framework species approach proves robust in restoring forest on fire prone invasive grass: A case study from Panama. Journal of Sustainable Forestry, v. 40, n. 2, p. 197-215, 2020

BRASIL. 2019. Statistical Yearbook of electricity 2018 baseline year. Brasília: Energy Research Office. Available at: http://www.epe.gov.br. Accessed in: April 15th 2020

CHERLET, M.; HUTCHINSON, C.; REYNOLDS, J.; HILL, J.; SOMMER, S. VON MALTITZ, G. World Atlas of Desertification. Publication Office of the European Union, 2018. 248p.

CLARKE, D. J. PEARCE, K. A.; WHITE, J. G. Powerline corridors: degraded ecosystems or wildlife havens? Wildlife Research, v. 33, n. 8, p. 615-626, 2006

CLARKE, D. J.; WHITE, J. G. Towards ecological management of Australian powerline corridor vegetation. Landscape and Urban Planning, v. 86, n. 3 p. 257-266, 2008 .

ÇOBAN, S.; BALEKOĞLU, S.; ÖZALP, G. Change in plant species composition on powerline corridor: a case study. Environmental Monitoring and Assessment, v. 191, n. 4, p. 200, 2019.

DAVIS, W. P. Analysis of faults in overhead transmission lines. 2012. 64 p. Master dissertation, California State University, Sacramento.

DOBBERTIN, M. Tree growth as indicator of tree vitality and of tree reaction to environmental stress: a review. European Journal of Forest Research, $v$. 124, n. 4, p. 319-333, 2005

DUMROESE, R. K: LANDIS, T. D.: PINTO, J. R.: HAASE, D. L.: WILKINSON, $K$ W.; DAVIS, A. S. Meeting forest restoration challenges: using the target plant concept. Reforesta, v. 1, n. 1, p. 37-52, 2016

ELLIOTT, S.; NAVAKITBUMRUNG, P.; KUARAK, C.; ZANGKUM, S. ANUSARNSUNTHORN, $V_{\text {. }}$ BLAKESLEY, D. Selecting framework tree species for restoring seasonally dry tropical forests in northern Thailand based on field performance. Forest Ecology and Management, v.184, n. 1-3, p. 177-191, 2003.

FERNANDES, M. F.; CARDOSO, D.; QUEIROZ, L. P. An updated plant checklist of the Brazilian Caatinga seasonally dry forests and woodlands reveals high species richness and endemism. Journal of Arid Environments, v. 174, p. 104079,2020

GROSSNICKLE, S. C. Why seedlings survive: influence of plant attributes. New Forests, v. 43, n. 5-6, p. 711-738, 2012.
GUEDES, R. S. ALVES, E. U. COSTA, E. M. T: SANTOS-MOURA, S. S. SILVA, R. S.; CRUZ, F. R. S. Avaliação do potencial fisiológico de sementes de Amburana cearenses (Allemão) A.C. Smith. Bioscience Journal, v. 29, n. 4, p. 859-866, 2013.

HALME, P.; ALLEN, K. A.; AUNINŠ, A.; BRADSHAW, R. H. W.; BRŪMELIS, G.; CADA, V.; CLEAR, J. L.; ERIKSSON, A. M.; HANNON, G.; HYVÄRINEN, E.; IKAUNIECE, S.; IRSEENAITEE, R.; JONSSON, B. G.; JUNNINEN, K.; KAREKSELA, S: KOMONEN, S. KOTIAHO S. S. KOUKI J. KUULUVAINEN T: MAZZIOTTA, M. NYHOLM. K: OLDÉN A. SHOROHOVA, E. STRANGE N: TOIVANEN T.; ILKKAVANHA-MAJAMAA, I.; WALLENIUS, T.; YLISIRNIÖ, Á. L.; ZIN, E. Challenges of ecological restoration: lessons from forests in northern Europe. Biological Conservation, v. 167, p. 248-256, 2013

HIROTA, M.; HOLMGREN, M.; VAN NES, H. G.; SCHEFFER, M. Global resilience of tropical forest and savanna to critical transitions. Science, v. 334, n. 6053, p. 232-235, 2011

INMET - INSTITUTO NACIONAL DE METEOROLOGIA. Brazilian climatological normals 1981 - 2010. Instituto Nacional de Meteorologia do Brasil, 2018. 753p.

KOUTOUAN-KONTCHOI, M. N.; PHARTYAL, S. S.; ROSBAKH, S.; KOUASSI, E. K.; POSCHLOD, P. Seed dormancy and dormancy-breaking conditions of 12 West African woody species with high reforestation potential in the forest-savanna ecotone of Côte d'Ivoire. Seed Science and Technology, v. 48, n. 1, p. 101-116, 2020.

KUMAR, R.; NAJAR, R. A.; GUPTA, K. B.; SAINI, R. G. Micropropagation protocol for Salvadora oleoides. Journal of Forestry Research, v. 30, n. 1, p. $87-93,2019$

LIMA JUNIOR, M. J. V. Manual de procedimentos de análise de sementes florestais. Universidade Federal do Amazonas, 2010. 145p.

LIMA T. L. FERREIRA R L C S SILVA J A A. ALVES JÚNIOR, F T. LIMA A. L. A.; CÉSPEDES, G. H. G.; BERGER, R.; LONGHI, R. V. Stump regrowth and estimation of reconstituting Caatinga shrub-tree biomass under forest management. Scientia Forestalis, v. 46, n. 119, p. 449-458, 2018.

LI, X.; LIN, Y. Do high-voltage power transmission lines affect forest landscape and vegetation growth: evidence from a case for southeastern of China. Forests, v. 10, n. 2, p. 162, 2019

LLORET, F.; CASANOVAS, C.; PEÑUELAS, J. Seedling survival of Mediterranean shrubland species in relation to root:shoot ratio, seed size and water and nitrogen use. Functional Ecology, v. 13, n. 2, p. 210-216, 1999

MACHADO NETO, A. P.; BRANDÃO, C. F. L. S.; DUARTE, B.; ALMIR, J.; MARANGON, L. C.; FELICIANO, A. L. P. Densidade e poder calorífico como base para prevencão de incêndios florestais sob linhas de transmissão. Nativa, v. 3, n. 1, p. $10-15,2015$

MAGGIONI, R. A. NETTO, E. R. LATOH L. P. KOEHLER, H. S: ZUFFELLATORIBAS, K. C. Viability of the mini-cutting technique in the production of Drimys brasiliensis Miers seedlings. Floresta, v. 50, n. 2, p. 1195-1202, 2020.

MAGUIRE, J. D. Speed of germination-aid in selection and evaluation for seedlings emergence and vigor. Crop Science, v. 2, n. 2, p. 176-177, 1962.

MILES, L. NEWTON, A. C.: DEFRIES, R. S.; RAVILIOUS, C.; MAY, I.; BLYTH, S. KAPOS, V: GORDON, J. A Global overview of the conservation status of tropical dry forests. Journal of Biogeography, v. 33, n. 3, p. 491-505, 2006.

SILVA, A. P. M.: SCHWEIZER, D.; MARQUES, H. R.; TEIXEIRA, A. M. C.: SANTOS, T. V. M. N.; SAMBUICHI, R. H. R.; BADARI, C. G. 'GAUDARE, U.; BRANCALION P. H. S. Can current native tree seedling production and infrastructure meet an increasing forest restoration demand in Brazil? Restoration Ecology, v. 25, n. 4, p. 509-515, 2017

OLIVEIRA, R. R.; ZAÚ, A. S. Impactos da instalação de linhas de transmissão sobre ecossistemas florestais. Floresta e Ambiente, v. 5, p. 184-191, 1998.

PAKKAD, G.; TORRE, F.; ELLIOTT, S.; BLAKESLEY, D. Selecting seed trees for a forest restoration program: a case study using Spondias axillaris Roxb. (Anacardiaceae). Forest Ecology and Management, v. 182, n. 1-3, p. 363-370, 2003

PAULSON, M.: BARDOS, P.; HARMSEN, J.; WILCZEK, J.; BARTON, $M$. EDWARDS, D. The practical use of short rotation coppice in land restoration. Land Contamination \& Reclamation, v. 11, n. 3, p. 323-338, 2003

PÉREZ, D. R.; FARINACCIO, F. M.; ARONSON, J. Towards a dryland framework species approach. Research in progress in the Monte Austral of Argentina. Journal of Arid Environments, v. 161, p. 1-10, 2019.

SILVA, R. B.; MATOS, V. P.; FARIAS, S. G. G.; SENA, L. H. M.; SILVA, D. Y. B. O. Germinácão e vigor de plântulas de Parkia platycephala Benth. em diferentes subbstratos e temperaturas. Revista Ciência Agronômica, v. 48 , n. diferentes substratos

SOUZA, M. A. VALE, A. T. Levantamento de plantas de baixa inflamabilidade em áreas queimadas de Cerrado no Distrito Federal e análise das suas propriedades físicas. Ciência Florestal, v. 29, n. 1, p. 181-192, 2019

STUEPP, C. A.; FRAGOSO, R. O.; MAGGIONI, R. A.; ZUFFELLATO-RIBAS, K. C.; WENDLING, . Vegetative rescue and ex vitro plants production system for Ginkgo biloba by cuttings and mini-cuttings. Revista Brasileira de Plantas Medicinais, v. 19, n. 2, p. 300-303, 2017.

XAVIER, F. A. Z.; OLIVEIRA, T. S.; ARAÚJO, F. S.; GOMES, V. S. Manejo da vegetação sob linhas de transmissão de energia elétrica na serra de Baturité. Ciência Florestal, v. 17, n. 4, p. 351-364, 2007 
WAGNER, D. L.; METZLER, K. J.; LEICHT-YOUNG, S. A.; MOTZKIN, G. Vegetation composition along a New England transmission line corridor and its implications for other trophic levels. Forest Ecology and Management, v. 327, p. 231-239, 2014
WAIBOONYA, P.; ELLIOTT, S. Sowing time and direct seeding success of native tree species for restoring tropical forest ecosystems in northern Thailand. New Forests, v. 51, n. 1, p. 81-99, 2020 